36 Kuo HK, Yen CJ, Chang $\mathrm{CH}$, Kuo CK, Chen JH, sorond F. Relation of C-reactive protein to stroke, cognitive disorders, and depression in the general population: systematic review and meta-analysis. Lancet Neurol 2005; 4 $371-80$

37 Berk M, Ng F, Dean O, Dodd S, Bush Al. Glutathione: a novel treatment target in psychiatry. Trends Pharmacol Sci 2008; 29: 346-51.

38 Berk M. Oxidative biology: new intervention opportunities in psychiatry. Acta Neuropsychiatrica 2007; 19: 259-60.

39 Galecki P, Szemraj J, Bienkiewicz M, Zboralski K, Galecka E. Oxidative stress parameters after combined fluoxetine and acetylsalicylic acid therapy in depressive patients. Hum Psychopharmacol 2009; 24: 277-86.

40 Wei YC, Zhou FL, He DL, Bai JR, Hui LY, Wang XY, et al. The level of oxidative stress and the expression of genes involved in DNA-damage signaling pathways in depressive patients with colorectal carcinoma. J Psychosom Res 2009; 66: 259-66.

41 Barry S, Clarke G, Scully P, Dinan TG. Kynurenine pathway in psychosis: evidence of increased tryptophan degradation. J Psychopharmacol 2009; 23 287-94.

42 Pasco JA, Williams L, Jacka FN, Ng F, Henry MJ, Nicholson GC, et al. Tobacco smoking as a risk factor for major depressive disorder: population-based study. Br J Psychiatry 2008; 193: 322-6.

43 Hamalainen J, Kaprio J, Isometsa E, Heikkinen M, Poikolainen K, Lindeman S, et al. Cigarette smoking, alcohol intoxication and major depressive episode in a representative population sample. J Epidemiol Community Health 2001; 55: 573-6.

44 Malhi GS, Berk M. Does dopamine dysfunction drive depression? Acta Psychiatr Scand 2007; 115 (suppl 433): 116-24.
45 Kangavari S, Matetzky S, Shah PK, Yano, J, Chyu KY, Fishbein MC, et al. smoking increases inflammation and metalloproteinase expression in human carotid atherosclerotic plaques. J Cardiovasc Pharmacol Ther 2004; 9: 291-8.

46 Blumenfeld Z, Boulman N, Leiba R, Siegler E, Shachar S, Linn R, et al. High C-reactive protein levels are associated with oral hormonal menopausal therapy but not with intrauterine levonorgestrel and transdermal estradiol. Scand J Clin Lab Invest 2007; 67: 257-63.

47 Danese A, Pariante CM, Caspi A, Taylor A, Poulton R. Childhood maltreatment predicts adult inflammation in a life-course study. Proc Natl Acad Sci USA 2007; 104: 1319-24.

48 Danese A, Moffitt TE, Pariante CM, Ambler A, Poulton R, Caspi A. Elevated inflammation levels in depressed adults with a history of childhood maltreatment. Arch Gen Psychiatry 2008; 65: 409-15.

49 Yuan G, Zhou L, Tang J, Yang Y, Gu W, Li F, et al. Serum CRP levels are equally elevated in newly diagnosed type 2 diabetes and impaired glucose tolerance and related to adiponectin levels and insulin sensitivity. Diabetes Res Clin Pract 2006; 72: 244-50.

50 Danesh J, Wheeler JG, Hirschfield GM, Eda S, Eiriksdottir G, Rumley A, et al. C-reactive protein and other circulating markers of inflammation in the prediction of coronary heart disease. N Engl J Med 2004; 350: 1387-97.

51 Pasco JA, Kotowicz MA, Henry MJ, Nicholson GC, Spilsbury HJ, Box JD, et al. High-sensitivity $\mathrm{C}$-reactive protein and fracture risk in elderly women. JAMA 2006; 296: 1353-5.

52 Nilsson K, Gustafson L, Hultberg B. C-reactive protein: vascular risk marker in elderly patients with mental illness. Dement Geriatr Cogn Disord 2008; 26: 251-6.

\title{
extra Destigmatising mental illness, House style
}

\section{Shabbir Amanullah}

David Shore and Paul Attanasio have done for mental health what many public education series have not been able to do: tackle stigma head on.

By portraying a narcissistic individual with brilliant diagnostic skills and an ability to say what many on occasion would like to but don't for fear of losing their licence, Hugh Laurie made House one of the most popular of TV serials. His character is a potent combination of genius and anger admired by all. 'He got it right, didn't he?'

House's breakdown and hospital admission showed how mental illness can affect anyone and, maybe more likely, the brilliant. Movies like Rain Man and A Beautiful Mind had an impact but mainly on those who identified with mental illness, because of either the nature of their work or personal circumstances. These movies were illness-based and to some extent predictable. House, on the other hand, by depicting a 'normal' physician becoming ill has comfortably punctured the 'will always be ill' myth. Recovering physicians fear being treated 'differently'. They often wonder how it would have been if they were admitted to the local psychiatric unit.

One Flew over the Cuckoo's Nest left an indelible negative image of psychiatry and how mental illness is treated and such a clear depiction of treatability combined with a fresh doctor-patient interface was long overdue. It may be early days to study the impact House's admission and treatment has had on the public but we should capitalise on this and target the stigma that resides within and then without.

As a physicians' body, we must strive to dispel myths about mental illness making the person 'incompetent'. Nothing can be farther from the truth - even House agrees! 